\title{
IMPACT OF EXPORT OF TRAVEL SERVICES ON CURRENT ACCOUNT BALANCE AND GROWTH IN MEDITERRANEAN COUNTRIES
}

\section{Maja Bacovica, Danijela Jacimovica , Julija Cerovic Smolovic ${ }^{a}$}

\begin{abstract}
Observing the expanding and high share of export of travel services in both GDP and total export of services in Mediterranean countries, we focus our research on travel service export in twelve countries from 1998 to 2018. We investigated both short-term and long-term significance of export of travel services for GDP growth in Mediterranean countries using the VAR and VECM model and the fixed-effects panel OLS model. In our analysis of significance of export of travel services on current account balance, we applied an accounting approach. Our application of the fixed-effects OLS model on the panel data with GDP growth rate as the dependent variable has shown that, in the short run, export of travel services has a positive impact on GDP growth. In the long run, Granger causality based on block exogeneity Wald tests evidenced that export of travel services has a positive impact on GDP growth, but only at the 10\% significance level. Following the accounting approach in our analysis of impact of export of travel services on overall current account balance, we evidenced a strong relevance of export of travel services in achieving current account balance equilibrium.
\end{abstract}

Keywords: Export of travel services, current account balance, growth, Mediterranean countries

JEL Classification: F14, F32, F43

\section{Introduction}

The relationship between export of goods and services and economic growth has generated vast research interest. This topic is even more relevant in developing countries due to their attempts to apply efficient growth strategies. The traditional theories have found that countries with a high share of manufacturing export in total export have achieved

a University of Montenegro, Faculty of Economics, Montenegro

Email: majab@ucg.ac.me, danijelaj@ucg.ac.me,julija@ucg.ac.me 
significant growth (Kalaitzi and Cleeve, 2018). Lately, however, export of services has become an increasingly important part of global trade, while the service sector has been considered a significant source of growth. The evolution towards more international trade in services could have strong implications for economies worldwide.

Expansion of the service sector, in terms of both its share in GDP and international trade, offers new sources of growth and stability. The share of export of services in the world GDP has more than doubled during the last 25 years, and the sector accounted for nearly a quarter of global trade in 2016 (IMF, 2018). It was similar in Europe, where the annual growth of export of services has been almost twice higher than the average growth of export of goods. The share of developing countries in global export of services has also grown, reaching 25 percent in 2016 (IMF, 2018). Trade in services is found to be less volatile than trade in goods, and it is thus seen as an important source of stability during periods of macroeconomic and financial turbulence (Loungani et al., 2017). While there is much positive evidence that the service sector growth has contributed to income growth and employment in short run, there are ongoing debates whether the service sector contributes to long-term economic growth (Moro, 2015).

From the international trade perspective, export of services is a source of foreign exchange earnings, and consequently, among other sources, determines the country's current account balance. Among services sold to non-residents, transport, travel, financial, services, telecommunications, information services, charges for the use of intellectual property and other business services are the most tradable. The balance of payment position has always been fragile for most (developed and less developed) countries. The problem became more evident in the recent financial crisis. Despite relatively extensive theoretical literature, there is a lack of cross-country empirical analyses of current account imbalances. Nevertheless, international travel has recorded strong growth during the last decade, causing growing research interest and debate in theoretical and empirical literature concerning its impact on economic growth and current account equilibrium.

Travel industry, or tourism, is a complex sector, composed of a very diverse series of industries and activities undertaken by visitors. Therefore, it increases value added in economy and is source of foreign exchange earnings, determining total current account balance of the country. International tourism has experienced significant growth in the twenty-first century, and it may be considered a potential strategic development sector, not only from an academic point of view (Cortes-Jimenez and Pulina, 2010).

The aim of the paper is to examine more adequately the relationship between revenues from export of travel services and GDP growth in the short and long run, and its impact on current account balance. Observing the high share of export of travel services in both GDP and total export of services in European Mediterranean countries (Greece, 
Italy, Spain, Portugal, France, Malta, Slovenia, Croatia, Cyprus, Montenegro, Albania and Turkey), we will focus our research on export of travel services, covering services that are purchased by non-residents during visits to the economy.

We will test the hypothesis that export of travel services is a significant determinant of GDP growth in the short and long run and of current account balance. We will investigate the significance of export of travel services for GDP growth in Mediterranean countries, using the VAR and VECM model, as well as a polled OLS (panel data, fixed effects). In our analysis of the significance of export of travel services for current account balance, we will apply an accounting approach.

The paper is structured into six sections. An introduction, with a theoretical background and the research objective were presented in the first section. The most relevant literature is reviewed in the Section 2, followed by an empirical analysis of export of travel trends in Mediterranean countries from 1998 to 2018. In Section 4, data and applied methodologies will be presented. In Section 5, we present the study results. The final section presents concluding remarks and recommendations for future research.

\section{Literature Review}

The relationship between tourism and economic growth in economies has received increasing attention and ongoing debate in recent years, equally in advanced and in developing or transitional economies (Sequeira and Campos, 2005). In their research into service trade and policy, Francois and Hoekman (2010) concluded that "services can be an engine of export growth for some countries". The research into developed countries has shown a very strong relationship between export of travel services and growth in the late 1990s in Austria (Walterskirchen, 1998) and Australia (Kulendran and Wilson, 2000).

The relationship between tourism development and economic growth can vary among countries: Lee and Chang (2008) found that this relationship is stronger in non-OECD countries (Asia, Latin America and Sub-Saharan Africa) than in OECD countries for the period 1990-2002. Bahar and Bozkurt (2010) and Samimi et al. (2011) found a significant impact of the tourism sector on economic growth in developing countries. Eugenio-Martin and Morales (2004) researched the relationship between tourism and economic growth for Latin American countries in the period 1985-1998. Their results showed that the tourism sector is a relevant source of growth in medium or low-income countries, though not necessarily in developed countries. Durbarry (2004) confirmed the relevance of the tourism industry in the case of Mauritius. Sequeira and Campos (2005), using appropriate panel data methods, found that tourism is a positive determinant of economic growth in both a broad sample of developing countries and a sample of poor 
countries. Contrary to previous contributions, their research showed that tourism is not more relevant in small countries than in a general sample.

Gokovali and Bahar (2006) and, much later, Aslan (2014) studied the contribution of tourism to economic growth, applying a panel data approach to Mediterranean countries for the period 1987-2002. They concluded that tourism has positive effects on economic growth. Different studies came to the same conclusions in the cases of Cyprus, Greece, Italy, Portugal, Malta and Spain (Balaguer and Cantavella-Jordá, 2002; Drisakis, 2004; Ivanov and Webster, 2006; Proenca and Soukiazis, 2008; Cortes-Jimenez and Pulina, 2010; Diaz de la Guardia et al., 2005).

Available research on transitional countries provides similar findings. "The service sector is more and more making a significant contribution to export growth in all countries, and at the same time represents a large opportunity to find new comparative advantages in trade for Central Eastern European (CEE) countries." (Mishra et al., 2011) Kordalska and Olczyk (2018) found that services dominate growth in the EU-15 countries and to a lesser extent in New Member States and accession countries. Chou (2013) argues that tourism development promotes economic growth in transition counties based on research in ten transition countries for the period 1988-2011. He found that the growth hypothesis holds for Cyprus, Latvia and Slovakia while reverse relationships were found for the Czech Republic and Poland.

Another very important angle of the research studies is to examine to what extent tourism and tourism revenues can contribute to the balance of payment position, as in most cases all countries that make a lot of effort to promote tourism have chronic problems balancing the balance of payment. "Despite the continuous efforts of developing countries to increase their exports, this strategy often adds little foreign exchange to their balance of payments, and so tourism is increasingly seen as something of a saviour", argues Durbarry (2004).

The importance of tourism as a generator of foreign exchange and its effects on balance of payment have been confirmed for developing countries by Hundt (1996). Recently, there are a growing number of sources in literature about this causality, mostly in developing countries (Caldereon et al., 2002; Konan and Maskus, 2016). Lorde et al. (2010) examined the case of Barbados, finding a positive impact. A positive relationships between tourism and growth and tourism contribution to balance of payment income has also been found for Turkey (Cetinas and Bektas, 2008; Arslantuk and Atan, 2012). The empirical findings suggest that the increase in tourism revenues in Turkey between 1984 and 2012 has resulted in a 14\% decrease of balance of payments deficit. Celik et al. (2013) and Alp and Gene (2015) also confirmed the positive impact of services on international trade and current account balance. The importance of tourism earnings to foreign exchange 
earnings and balance of payment in early development phases in Greece was addressed in the work of Papadopoulos and Mirza (1986); also in Italy (Formica and Uysal, 1996). Tourism has a favourable early effect in closing the gap in foreign trade and the balance of payments of CEE countries, too (Hall, 1998). For most of the Western Balkan countries, balance of payment has been in chronic deficit (Bartlett, 2009). Governments therefore view tourism as a catalyst for national and regional development, raising employment and exchange earnings and reducing balance of payments disequilibrium (Priniotaki and Kapsisi, 2008). For example, in Albania the tourist sector has a positive impact on the balance of payments and secondly, exports of services in Albania are mostly supported in tourism exports (Thano, 2015).

That is why the authors of this research wanted to extend the research and examine the impact of tourism revenues on the still high current deficit in some European countries, where tourism has had a significant impact on service income in the past and present .

\section{Trends in Export of Travel Services, Current Account Balance and GDP in Mediterranean Countries from 1998 to 2018}

European Mediterranean countries are largely service-oriented countries with a high share of export of services in their total export. The sample represents EU member countries (5), new member states (4), Western Balkan countries (2) and Turkey. Export of services represented more than $50 \%$ of the total export in 2018 in six countries of the sample (Greece, Croatia, Cyprus, Malta, Montenegro and Albania), while in Italy, Slovenia and Turkey it was lower than $30 \%$ of the total export of goods and services. In other countries in the sample (France, Spain, Portugal) it was between 30 and 50\%. However, their economies have evolved very differently during the last decades, which has produced very different paths of economic growth and importance of service sector development, particularly tourism in certain phases of growth. This adds relevancy to research investigating its impact on economic growth and current account balance.

The share of export of travel services in GDP is high in the all countries in the sample; it is equal to $8.87 \%$ on average for all the countries in the sample based on available data for the period 1998-2018. The share of export of travel services in GDP has grown in most European Mediterranean countries, while in Italy and Turkey it has been stable for the same period. At the country level, Montenegro has the largest average share of export of travel services in GDP (18.8\%), followed by Cyprus (16.9\%), Malta (16.4\%) and Croatia (15.5\%). Export of travel services is dominant in the exporting service sectors of eight countries in the sample, with its share in total export of services more than $40 \%$ in 2018 (Greece, Spain, Croatia, Italy, Portugal, Montenegro, Turkey and Albania). 
At the individual country level, annual growth in export of travel services was significant in all the countries in the sample, but the most significance was evidenced in Italy, Cyprus, Croatia, and especially in Montenegro and Albania, which is very important due to their, although improved, still high current account balance.

The analysis of the current account balance in the same group of countries, in the period 1998-2018, has shown that in many countries, current account deficit had shifted to a surplus ${ }^{1}$. Also, the average annual GDP growth rates were lower in the last decade compared to the previous one. Although the aim of this research is not to investigate determinants of slower growth, it is relevant to see the impacts of growing tourism sector.

\section{Data, Sample and Methodology}

\subsection{Data and sample}

Data used in the research were extracted from the Eurostat database (country-level data), the World Bank database (world-level data), while some computations were also necessary. The following indicators were used: gross domestic product, gross fixed capital formation, unemployment rate, total employment and employment in sectors, current account balance, export of goods, export of services and export of travel services for twelve countries in the sample defined in first section for the period 1998-2018.

The sample was defined combining two criteria: the share of export of travel services in total export of services and geographical criteria. All the countries in the sample are European Mediterranean countries (Greece, Italy, Spain, Portugal, France, Malta, Slovenia, Croatia, Cyprus, Montenegro, Albania and Turkey).

\subsection{Methodology}

To estimate the impact on GDP growth in the short and long run, we follow the ELG hypothesis approach (export-led growth), applying the VAR and VECM model to the panel data and pooled OLS (fixed effects, panel data). As Herzer et al. (2006) pointed out, the "ELG hypothesis postulates that export expansion is a key factor in promoting long-run growth". Panel data models secure reduction in endogeneity, allowing country-specific effects to be correlated with regressors (fixed-effects models) or not (random-effects models) (Sequeira and Campos, 2005). Furthermore, panel data increase the sample size and thus allow higher degrees of freedom and more accurate statistical tests. The VAR and VECM models are considered to be a standard tool in applied econometrics (Holtz-Eakin et al., 1988), especially when examining the impact between variables in both the short and long run.

1 Data available on request. 
For the analysis of a country's external sustainability, available literature suggests two methodologies. The first one applies an accounting framework, while the second one aims to combine an accounting framework with observed empirical relationships between current account balance and its determinants (Cusolito and Nedeljkovic, 2013). As the aim of our research is to determine the impact of foreign exchange earnings from export of travel services on current account balance, but not to analyse impact of determinants affecting earnings, an accounting approach, explained in details in Section 4.2.2, will be applied.

\subsubsection{Model (VAR and VECM), pooled OLS}

Following the approach of Herzer et al. (2006) and Kalaitzi and Cleeve (2018), aggregate production of an economy can be expressed as a function of capital stock, labour and primary exports and imports:

$$
Y_{t}=A_{t} K_{t}^{\alpha} L_{t}^{\beta}, 0<\alpha+\beta<1,
$$

where $Y_{t}$ denotes the aggregate production of the economy at the time $t, A_{t}$ is the total factor productivity, and $K_{t}$ and $L_{t}$ represent the capital stock and labour, respectively. The constants $\alpha$ and $\beta$ represent the share of capital and labour in income.

In addition, it is assumed that total factor productivity can be expressed as a function of primary export $P X_{t}$ primary imports $I M P_{t}$ and other exogenous factors $C_{t}$ :

$$
A_{t}=f(P X, I M P, C)=P X^{\gamma} I M P^{\theta} C .
$$

A combination of Equations 1 and 2 is then:

$$
Y_{t}=C_{t} K_{t}^{\alpha} L_{t}^{\beta} P X_{t}^{\gamma} I M P_{t}^{\theta},
$$

where $\alpha, \beta, \gamma$ and $\theta$ represent the elasticities of production with respect to the inputs of production: $K_{t}, L_{t}, P X_{t}$, and $I M P_{t}$.

After taking natural logs, the following equation is obtained:

$$
L Y_{t}=c+\alpha L K_{t}+\delta L L_{t}+\gamma L P X_{t}+\theta L I M P_{t}+\varepsilon_{t},
$$

where $c$ is the intercept, $\alpha, \beta, \gamma, \delta, \zeta$ and $\theta$ are constant elasticities and $\varepsilon_{t}$ is the error term.

In their research, Gokovali and Bahar (2006) proposed a model estimating the impact of gross fixed capital formation as a percentage of GDP (GFCFGDP), tourism receipts as a percentage of export (TOUEX) and the growth of labour force $(G L F)$ as explanatory variables for GDP growth rate $(G G D P)$. 


$$
G G D P=\beta_{0}+\beta_{1} G F C F G D P+\beta_{2} T O U E X+\beta_{3} G L F+\mu .
$$

Combining both approaches (Equations 1 and 5), we assume that total factor productivity can be expressed as a function of export of goods $P X_{t}$, export of services minus travel $S X_{t}$, export of travel services $T S X_{t}$, import of goods and services $I M P_{t}$ and other exogenous factors $C_{t}$ :

$$
A_{t}=f\left(P X_{t}, S X_{t} T S X_{t}, I M P_{t}, C_{t}\right)=P X_{t}^{\gamma} S X_{t}^{\delta} T S X_{t}^{\vartheta} I M P_{t}^{\theta} C_{t},
$$

A combination of Equations 1 and 6 is then:

$$
Y_{t}=C_{t} G F C F_{t}^{\alpha} L_{t}^{\beta} P X_{t}^{\gamma} S X_{t}^{\delta} T S X_{t}^{\vartheta} I M P_{t}^{\theta},
$$

where $\alpha, \beta, \gamma, \delta, \zeta$ and $\theta$ represent the elasticities of production with respect to the inputs of production: $G F C F_{t}, L_{t}, P X_{t}, T S X_{t}$, and $I M P_{t}$.

After taking natural logs, the following equation is obtained:

$$
L Y_{t}=c+\alpha L G F C F_{t}+\delta L L_{t}+\gamma L P X_{t}+\delta L S X_{t}+\vartheta L T S X_{t}+\theta L I M P_{t}+\varepsilon_{t},
$$

where $c$ is the intercept, $\alpha, \beta, \gamma, \delta, \zeta$ and $\theta$ are constant elasticities and $\varepsilon_{t}$ is the error term.

We will apply a panel estimation technique, combining both time series and cross sections.

\subsubsection{Measurement of effects of growth of export of travel services on current account balance}

As pointed out by Cusolito and Nedeljkovic (2013), analysis of external imbalances and sustainability may be performed applying two methodologies: an accounting framework and a combination of an accounting framework with observed empirical relationships between current account balance and its determinants. For the purpose of our research, as our aim is to identify the existence of an impact of export of travel on current account balance, we apply an accounting approach.

Therefore, current account balance in the country $x$ in the period $t$ is equal to:

$$
C A B_{t}=T B_{t}+F I_{t}+T_{t}
$$

where $C A B_{t}$ is current account balance in the period $t, T B_{t}$ stands for balance of trade of goods and services in the period $t ; F I_{t}$ is net factor income in the period $t$, while $T_{t}$ is net current transfers in the period $t$. 
Equation 9 may be rewritten as:

$$
C A B_{t}=E g_{t}+E t_{t}+E o_{t}-I g_{t}-I s_{t}+F I_{t}+T_{t},
$$

where $E g_{t}$ is export of goods in the period $t$; $E t_{t}$ represents export of travel services in the period $t$, while represents export of other services (other than travel) in the period $t$; $I g_{t}$ is import of goods in the period $t$ and $I s_{t}$ is import of services in the period $t$.

Annual change in $C A B$ is equal to:

$$
\begin{aligned}
& C A B_{t+1}-C A B_{t}=E g_{t+1}-E g_{t}+E t_{t+1}-E t_{t}+E o_{t+1}-E o_{t}-\left(I g_{t+1}-I g_{t}\right)- \\
& -\left(I s_{t+1}-I s_{t}\right)+F I_{t+1}-F I_{t}+T_{t+1}-T_{t}
\end{aligned}
$$

If we divide all with $C A B_{t+1}-C A B_{t}$, while $C A B_{t+1}-C A B_{t} \neq 0$,

$$
\frac{E t_{t+1}-E t_{t}}{C A B_{t+1}-C A B_{t}}=1-\frac{E g_{t+1}-E g_{t}+E o_{t+1}-E o_{t}-\left(I g_{t+1}-I g_{t}\right)-\left(I s_{t+1}-I s_{t}\right)+F I_{t+1}-F I_{t}+T_{t+1}-T_{t}}{C A B_{t+1}-C A B_{t}}
$$

we can measure annual change in export of travel services per unit of annual change in current account balance. Similarly, we can estimate the contribution of other components to change in current account balance as well (change in export of goods, change in export of services other than travel, etc.)

\section{Results and Key Findings}

\subsection{VAR and VECM model; Granger causality based on block exogeneity Wald tests, pooled OLS (fixed effects, panel data)}

To estimate the impact of export of travel services on GDP growth, using panel data, we estimated a model as explained in Section 4.1 (Equation 8). The variables used in our research are as follows: log GDP (gross domestic product), log GFCF (gross fixed capital formation), $\log L$ (labour), $\log G$ (total export of goods), $\log S$ (export of services minus export of travel services), $\log \mathrm{T}$ (export of travel services), log IMP (total import) for the twelve Mediterranean countries for the period 1998-2018. Descriptive statistics are presented in the following Table 1.

Since we worked with panel data for 12 countries and 21 years (1998-2018), we examined the existence of unit-root tests, adequate for panel data. Before applying cointegration techniques, we used panel unit root tests to determine the order of integration between all the series in our dataset. We employed four different types of panel unit root tests: Levin-Lin-Chu (LLC) (2002), Im-Pesaran-Shin (IPS) (2003), ADF Fisher Chi-Square and PP-Fisher Chi-Square unit root tests. All four mentioned tests for stationarity under 
the null hypothesis imply the existence of a unit root, while the alternative hypothesis implies stationarity. The first mentioned test investigates existence of unit root using a common process, while the rest consider the unit root using an individual process.

Table 1: Descriptive statistics of the variables

\begin{tabular}{l|r|r|r|r|r|r|r}
\hline & \multicolumn{1}{|c|}{$\log$ GDP } & \multicolumn{1}{c|}{$\log \boldsymbol{G}$} & $\log$ GFCF & \multicolumn{1}{c|}{$\log \boldsymbol{L}$} & \multicolumn{1}{c}{$\log \boldsymbol{S}$} & $\log \boldsymbol{T}$ & $\log \boldsymbol{I M P}$ \\
\hline Mean & 11.44 & 9.69 & 9.93 & 7.84 & 8.86 & 8.71 & 10.57 \\
\hline Median & 11.82 & 9.78 & 10.00 & 7.83 & 8.85 & 8.88 & 10.70 \\
\hline Maximum & 14.67 & 13.15 & 13.20 & 10.23 & 12.16 & 11.04 & 13.57 \\
\hline Minimum & 7.68 & 5.55 & 6.20 & 4.96 & 3.19 & 5.40 & 6.94 \\
\hline Std. Dev. & 2.11 & 2.26 & 2.09 & 1.82 & 1.76 & 1.48 & 1.75 \\
\hline Skewness & -0.01 & -0.08 & 0.02 & -0.11 & -0.37 & -0.13 & -0.003 \\
\hline Kurtosis & 1.65 & 1.83 & 1.64 & 1.62 & 2.81 & 1.74 & 1.86 \\
\hline Jarque-Bera & 18.33 & 13.58 & 18.52 & 19.54 & 5.48 & 16.62 & 13.23 \\
\hline Probability & 0.000105 & 0.001124 & 0.000095 & 0.000057 & 0.06 & 0.000246 & 0.001 \\
\hline Sum & $2,757.26$ & $2,247.42$ & $2,393.45$ & $1,880.93$ & $2,002.62$ & $2,117.68$ & $2,578.88$ \\
\hline Sum Sq. Dev. & $1,069.97$ & $1,184.86$ & $1,051.14$ & 790.92 & 699.82 & 533.12 & 747.45 \\
\hline Observations & 241 & 232 & 241 & 240 & 226 & 243 & 244 \\
\hline
\end{tabular}

Source: Authors' calculation

We performed testing for level stationarity, and all the variables are not level stationary, so we further investigated whether they are I(1). Therefore, we examined the first differences of the variables again using the same unit root tests. It is evident that the first differences of the variables are stationary for each of the unit root tests used. This leads to the final conclusion that all the variables are integrated of order 1 (I(1)), so we could proceed with cointegration testing. Afterwards, we performed a Kao residual cointegration test for panel data (Kao, 1999). The residual-based tests were constructed on the basis of the Engle and Granger (1987) test in a time series framework and used residuals of the panel static regression to construct the test statistics. The Kao test has a null hypothesis of no cointegration ${ }^{2}$.

2 Detailed results are available on request. 
Since the variables are integrated of order one and cointegrated, we applied VAR and VECM models, in order to produce Granger causality based on block exogeneity Wald tests. The lag length is determined according to the Hannan-Quinn information criterion (selected lag length is 2), while the diagnostic tests showed that the residuals are normal and homoscedastic, with no evidence of serial correlation. Thus, the assumptions of the model are fulfilled and we can proceed with Granger causality.

Table 2: Granger causality based on block exogeneity Wald tests

\begin{tabular}{l|c|c|c|c|c|c|c}
\hline \multirow{2}{*}{$\begin{array}{l}\text { Dependent } \\
\text { variable }\end{array}$} & \multicolumn{7}{|c}{ Source of causation } \\
\cline { 2 - 8 } & $\begin{array}{c}\log \text { GDP } \\
\left(x^{2}=2\right)\end{array}$ & $\begin{array}{c}\log G F C F \\
\left(x^{2}=2\right)\end{array}$ & $\begin{array}{c}\log L \\
\left(x^{2}=2\right)\end{array}$ & $\begin{array}{c}\log G \\
\left(x^{2}=2\right)\end{array}$ & $\begin{array}{c}\log S \\
\left(x^{2}=2\right)\end{array}$ & $\begin{array}{c}\log T \\
\left(x^{2}=2\right)\end{array}$ & $\begin{array}{c}\log I M P \\
\left(x^{2}=2\right)\end{array}$ \\
\hline $\log$ GDP & - & 2.02 & $6.08^{* *}$ & 0.22 & $4.99^{*}$ & $4.77^{*}$ & 2.39 \\
\hline $\log$ GFCF & $13.88^{* * *}$ & - & $5.25^{*}$ & 2.18 & 2.01 & 1.02 & 1.11 \\
\hline $\log L$ & 3.75 & $14.29^{* * *}$ & - & 0.17 & 0.16 & 2.26 & $4.87^{*}$ \\
\hline $\log G$ & $9.28^{* * *}$ & 3.52 & 1.87 & - & $6.06^{* *}$ & $14.64^{* * *}$ & $10.59^{* * *}$ \\
\hline $\log S$ & $6.32^{* *}$ & $5.19^{*}$ & 2.14 & $13.10^{* * *}$ & - & 0.46 & $7.61^{* *}$ \\
\hline $\log T$ & 3.45 & 2.59 & $5.14^{*}$ & 1.09 & 3.09 & - & 0.29 \\
\hline $\log I M P$ & 3.60 & 0.89 & 1.10 & 1.38 & 0.06 & $10.78^{* * *}$ & - \\
\hline
\end{tabular}

Notes: ${ }^{* * *}, * *$ and ${ }^{*}$ indicate significance at the level of $1 \%, 5 \%$ and $10 \%$ respectively. The value in parenthesis represents the degrees of freedom.

Source: Authors' calculation

The results of Granger causality based on Block exogeneity Wald tests are presented in Table 2. There is a direct long-run causality, running from GDP to gross fixed capital formation $(\log G F C F)$ and to export of goods $(\log G)$, at the $1 \%$ significance level. There is also evidence that GDP Granger-causes services export minus travel $(\log S)$, at the 5\% significance level. At the same time, a significant causality runs from gross fixed capital formation $(\log G F C F)$ to labour $(\log L)$, at the $1 \%$ significance level, and to services export minus travel $(\log S)$, at the $10 \%$ significance level. Regarding labour, it strongly Granger-causes GDP $(\log G D P)$, at the 1\% level of significance, while it Granger-causes gross fixed capital formation $(\log G F C F)$ and export of travel services $(\log T)$, at the $10 \%$ significance level. Moreover, there is a direct long-run causality, running from export $(\log G)$ to export of services minus travel $(\log S)$, at the $1 \%$ significance level. Simultaneously, export of services minus travel $(\log S)$ Granger-causes export of goods $(\log G)$ at the $5 \%$ significance level, and GDP at the $10 \%$ significance level. A significant causality runs from 
export of travel services $(\log T)$ to export of goods $(\log G)$ and to import of goods and services $(\log I M P)$, at the $1 \%$ significance level, and to GDP $(L G D P)$, at the $10 \%$ significance level. Finally, import of goods and services $(\log I M P)$ Granger-cause export of goods $(\log G)$ at the $1 \%$ significance level, export of services minus travel $(\log S)$ at $5 \%$, and labour $(\log L)$, at the $10 \%$ significance level.

We also estimated the impact of gross fixed capital formation as a percentage of GDP $(G F C F G D P)$, tourism receipts as a percentage of export (TOUEX) and the growth of labour force $(G L F)$ as explanatory variables for GDP growth rate $(G G D P)$. That is a methodology using a panel data approach proposed by Gokovali and Bahar (2006), as expressed in Equation 5. The results are summarized in Table 3.

Table 3: Estimation results (dependent variable is GGDP)

\begin{tabular}{l|c|c|c}
\hline Variables & Pooled OLS & Fixed effects & Random effects \\
\hline C & $\begin{array}{c}0.86^{* * *} \\
(<2.2 \mathrm{e}-16)\end{array}$ & - & $\begin{array}{c}0.86^{* * *} \\
(<2.20 \mathrm{e}-16)\end{array}$ \\
\hline GFCFGDP & $\begin{array}{c}0.54^{* * *} \\
(2.84 \mathrm{e}-11)\end{array}$ & $\begin{array}{c}0.59^{* * *} \\
(8.51 \mathrm{e}-10)\end{array}$ & $\begin{array}{c}0.55^{* * *} \\
(5.74 \mathrm{e}-11)\end{array}$ \\
\hline TOUEX & $0.02(0.54)$ & $0.12^{* *}(0.02)$ & $0.02(0.43)$ \\
\hline GLF & $0.06(0.21)$ & $0.04(0.47)$ & $0.06(0.26)$ \\
\hline F tests & $23.73^{* * *}(3,216)$ & $21.65^{* * *}(3,205)$ & $32.51^{* * *}(3,216)$ \\
\hline Durbin-Watson statistic & $(2.59 \mathrm{e}-13)$ & $(3.20 \mathrm{e}-12)$ & $1.22 \mathrm{e}-16)$ \\
\hline Hausman & $1.79^{* *}(0.05)$ & $2.03(0.59)$ & $1.83^{*}(0.08)$ \\
\hline
\end{tabular}

Source: Authors' calculation

The results for the pooled OLS (ordinary least squares) are reported for comparison with a fixed-effects and a random-effects model. However, we performed the Lagrange multiplier test (Breusch-Pagan) for balanced panels. The null hypothesis of this test implies no evidence of significant differences across countries and a simple OLS regression can be run. Since the results of this test strongly reject the null hypothesis, we further examined the fixed-effects and random-effects model.

The Hausman test was used in order to choose between fixed-effects and randomeffects models in panel data. The random-effects model is preferred under the null hypothesis due to its higher efficiency. The alternative hypothesis means that the fixedeffects model is at least consistent and preferred. At the 5\% significance level, the null 
hypothesis is rejected and the preferred model is fixed-effects. So, only the results of the preferred model are discussed.

The fixed-effects model estimation results indicate that proxies for capital and tourism positively affect the GDP growth rate in selected countries. While a $1 \%$ increase in investment share of GDP increases the growth rate by $59 \%$, a $1 \%$ percentage increase in tourism receipts in export increases the growth rate by $12 \%$.

\subsection{Annual changes in export of goods, travel services and other services and current account balance}

Following the methodology presented in Section 4.2.2, we estimated indicators of contributions of annual change in export of travel services (ET), export of goods (EG) and export of other services (EO) to annual change in current account balance (CAB) for the Mediterranean countries for the period 1998-2018. As we observed a large improvement in current account balances in some countries during the last decade, we also split the time frame into two parts, from 1998 to 2008, and from 2009 to 2018 (Table 4).

Table 4: Average annual change in export of goods, travel services and other services, per average annual change in current account balance, Mediterranean countries, 1998-2018

\begin{tabular}{|c|c|c|c|c|c|c|c|}
\hline & CAB & ET & EG & EO & \multirow{2}{*}{ TCAB } & \multirow{2}{*}{ GCAB } & \multirow{2}{*}{ OCAB } \\
\hline & \multicolumn{4}{|c|}{ Average annual change (million $€$ ) } & & & \\
\hline & \multicolumn{7}{|c|}{ 1998-2018 } \\
\hline Mean & 36.2 & 482.2 & 3742.3 & $1,237.5$ & 0.16 & 0.41 & 0.09 \\
\hline $\operatorname{Max}$ & $57,064.0$ & $6,378.7$ & $45,382.0$ & $16,001.0$ & 22.89 & 35.30 & 24.76 \\
\hline Min & $-31,418.0$ & $-7,093.7$ & $-76,462.0$ & $-9,711.0$ & -12.94 & -47.75 & -22.19 \\
\hline \multirow[t]{2}{*}{ Std. Dev. } & $8,616.0$ & $1,366.3$ & $12,317.4$ & $3,066.1$ & 2.72 & 7.07 & 3.12 \\
\hline & \multicolumn{7}{|c|}{ 1998-2008 } \\
\hline Mean & $-2,764.0$ & 407.1 & $4,190.9$ & $1,291.5$ & 0.01 & 0.31 & 0.16 \\
\hline $\operatorname{Max}$ & $7,968.0$ & $6,378.7$ & $40,038.0$ & $10,172.6$ & 7.81 & 35.30 & 24.76 \\
\hline Min & $-31,418.0$ & $-2,189.4$ & $-6,117.0$ & $-5,977.0$ & -11.00 & -47.75 & -5.62 \\
\hline \multirow[t]{2}{*}{ Std. Dev. } & $6,038.2$ & $1,135.5$ & $8,817.6$ & $2,515.6$ & 1.83 & 6.75 & 2.95 \\
\hline & \multicolumn{7}{|c|}{ 2009-2018 } \\
\hline Mean & $2,446.8$ & 546.8 & $3,356.0$ & $1,191.1$ & 0.29 & 0.50 & 0.03 \\
\hline $\operatorname{Max}$ & $57,064.0$ & $5,634.0$ & $45,382.0$ & $16,001.0$ & 22.89 & 29.09 & 10.50 \\
\hline Min & $-25,025.0$ & $-7,093.7$ & $-76,462.0$ & $-9,711.0$ & -12.94 & -31.16 & -22.19 \\
\hline Std. Dev. & $9,730.9$ & $1,539.7$ & $14,707.5$ & $3,481.3$ & 3.29 & 7.37 & 3.28 \\
\hline
\end{tabular}

Source: Author's estimation 
Our analysis showed that the largest average annual absolute growth in the total period and both sub-periods was evidenced in export of goods, followed by export of other services, but larger in the first sub-period (1998-2008). The average annual change in export of travel services increased in the second sub-period (after 2009). The growth in export of goods contributed to the growth in current account balance (GCAB) the most (0.41 per unit). However, although the absolute annual growth in export of travel services was lower than that in export of other services due to the high share in total export of services, the contribution to the change in current account balance (TCAB) was higher $(0.16$ per unit compared to 0.09 per unit) for the total period. In the earlier sub-period (1998-2008), the contribution of the change in export of other services (OCAB) to the change in current account balance was larger, but after 2009, the change in export of travel services contributed to the change in current account balance more ( 0.29 per unit, compared to 0.03 per unit in the case of other services).

The results of this study are comparable with results obtained by Alp and Gene (2015), who observed a positive relationship between travel receipts and current account balance in the case of Turkey.

\section{Conclusion}

Services, being of increasing importance in international trade and playing an important role in affecting productivity and growth, have attracted growing research interest recently. Travel services, as a significant sector in Mediterranean countries, and even dominant in trade in services in some of them, determine not only current account balance in respective countries, but also their production volume.

Theoretical and empirical research has confirmed relevance of export of travel services for current account balance improvements, particularly during the last decade. Research done in this study has confirmed the hypothesis that revenues from export of travel services reduce current account deficit.

In terms of its impact on GDP growth, application of pooled OLS (panel data, fixed effects model) with GDP growth rate as the dependent variable, has shown that, in the short run, export of travel services has a positive impact on GDP growth, and in the long run, the results of Granger causality based on block exogeneity Wald tests confirmed that export of travel services has a positive impact on GDP growth, but only at the $10 \%$ significance level. If we accept a reasonable 5\% significance level, export of travel services does not have a positive impact on GDP growth in the long run. This may be explained with sectoral contribution to total factor productivity growth, and evidence in literature showing that an increase in the share of services in GDP reduces both aggregate total factor productivity 
(TFP) growth and volatility, thus reducing GDP growth and volatility; similar results were presented in earlier studies (Formica and Uysal, 1996; Hundt, 1996). Chou (2013) showed that a causal direction among tourism spending and growth exists in countries in transition (Bulgaria, Romania and Slovenia).

The contribution of this research to overall literature may be divided into two parts. The first one, related to impact of tourism on GDP growth, has shown short-run positive effects, but long-run only at the $10 \%$ significance level. This is in line with results obtained by Badulesku et al. (2018), where it was confirmed that, in specific periods of time, tourism can stimulate economic growth in the short run, but later on, the development of the economy can support expansion of tourism, not vice versa.

The second contribution is estimation of impact of export of travel services on current account equilibrium using the most recent data for Mediterranean countries, as a study at this level but also over such a time frame, to the best of our knowledge, is not available in literature yet. Studies by Celik et al. (2013), Alp and Gene (2015), Bartlett (2009) and Thano (2015) also confirm the relevance of revenues from export of travel services, but on different samples and time frames. The study results have even more significance due to the fact that international tourist arrivals in EU countries are expected to grow by $2.1 \%$ on average each year until 2025 , compared to an annual average of $2.4 \%$ in the period 1995-2010. ${ }^{3}$

From a policy perspective, as export of travel services has a positive impact on short-term growth, but is also a very important determinant of sustainable current account equilibrium, economies dealing with both unemployment and current account deficit (e.g., Montenegro and Albania) should adjust their policies to promote growth in tourism.

Further research may be aimed at analysis of previously listed determinants, in both directions: their impact on travel and tourism, but also impact of travel and tourism on the environment and infrastructure, as their development may encourage growth in other sectors of an economy, contributing to stable long-run growth.

\section{References}

Alp, E., Gene, E. (2015). The Relation between Current Account Deficit and Tourism: The Case of Turkey. International Journal of Economics and Financial Issues, 5(2), 448-453.

Arslanturk, Y., Atan, S. (2012). Dynamic Relation between Economic Growth, Foreign Exchange and Tourism Income: An Econometric Perspective on Turkey. Journal of Business, Economics \& Finance, 1(1), 30-37.

UNWTO Tourism Highlights 
Arslanturk, Y., Balcilar, M., Ozdemir, Z. (2011). Time-varying Linkages between Tourism Receipts and Economic Growth in a Small Open Economy. Economic Modelling, 28(1-2), 664-671, https://doi.org/10.1016/j.econmod.2010.06.003

Aslan, A. (2014). Tourism Development and Economic Growth in the Mediterranean Countries: Evidence from Panel Granger Causality Tests. Current Issues in Tourism, 17(4), 363-372, https://doi.org/10.1080/13683500.2013.768607

Badulesku, A., Silmut, R., Badulesku, D. (2018). The Complex Relationship between International Tourism Demant and Economic Growth: An Analysis on Central and Eastern European Economics. Amfiteatry Economic, 20(12), 935-950, https://doi. org/10.24818/EA/2018/S12/935

Bahar, O., Bozkurt, K. (2010). Tourism and Economic Growth Relationship in Developing Countries: Dynamic Panel Data Analysis. Anatolia: Turizm Araştırmaları Dergisi, 21(2).

Balaguer, J., Cantavella-Jorda, M. (2002). Tourism as a Long-run Economic Growth Factor: the Spanish Case. Applied Economics, 34(7), 877-884, https://doi.org/10.1080/00036840110058923

Calderon, C., Chong, A., and Loayza, N. (2002). Determinants of Current Account deficits in Developing Countries. The B.E. Journal of Macroeconomics 2(1). https://doi.org/10.2202/1534-6005.1021

Celik, A., Ozcan, S., Topcuoglu, A., et al. (2013). Effects of the Tourism Industry on the Balance of Payments Deficit. Anatolia, An International Journal of Tourism and Hospitality Research, 24(1), 86-90, https://doi.org/10.1080/13032917.2013.772529

Cetintas, H., Bektas, C. (2008). Türkiye'de Turizm ve Ekonomik Büyüme Arasındaki Kısa ve Uzun Dönemli İlişkiler (The Long and Short Term Relationships between Tourism and Economic Growth in Turkey). Anatolia: Turizm Araştırmaları Dergisi, 19(1), 37-44.

Cihangir, M., Erkan, B., Harbahougly, M. (2014). The Effect on Current Account on Net Tourism Revenues in Turkey. European Scientific Journal, 10(3).

Cortes-Jimenez, I., Pulina, M. (2010). Inbound Tourism and long-run economic growth. Current Issues in Tourism, 13(1), 61-74, https://doi.org/10.1080/13683500802684411

Cusolito, A., Nedeljkovic, M. (2013). Toolkit for the Analysis of Current Account Imbalances. Washington, DC: The World Bank.

Devadas, S., Loyaza, N. (2018). When is a Current Account Deficit Bad? The World Bank. Available at: http://documents.worldbank.org/curated/en/507731538487989157/ When-is-a-Current-Account-Deficit-Bad

Diaz de la Guardia, C., Molero Zayas, J., Valadez, P. (2005). International Competitiveness in Services in Some European Countries: Basic Facts and a Preliminary Attempt of Interpretation. Working Paper No. 01/05.

Durbarry, R. (2004). Tourism and Economic Growth: The Case of Mauritius. Tourism Economics, 10(4), 389-401, https://doi.org/10.5367/0000000042430962 
Engle, R. F., Granger, C. W. J. (1987). Co-integration and Error-Correction: Representation, Estimation and Testing. Econometrica, 55(2), 251-276, https://doi.org/10.2307/1913236

Eugenio-Martin, J. L., Morales, N. M., Scarpa, R. (2004). Tourism and Economic Growth in Latin America Countries: A Panel Data Approach. FEEM. Working Paper No. 26.2004, https://doi.org/10.2139/ssrn.504482

Formica, S., Uysal, M. (1996). The Revitalization of Italy as a Tourist Destination. Tourism Management, 17(5), 323-331, https://doi.org/10.1016/0261-5177(96)00032-5

Francois, J., Hoekman, B. (2010). Services Trade and Policy. Journal of Economic Literature, 48, 642-692, https://doi.org/10.1257/jel.48.3.642

Gable Lundstrom, S., Mishra, S. (2011). Service Export Sophistication and Europe's New Growth Model. The World Bank. Policy Research Working Paper No 5793, https://doi.org/10.1596/1813-9450-5793

Gafar, J. (1978). An Analysis of Import Substitution in a Developing Economy: the Case of Jamaica. Caribbean Studies, 18(3/4), 139-156.

Gokovali, U., Bahar, O. (2006). Contribution of Tourism to Economic Growth: A Panel Data Approach. Anatolia: An International Journal of Tourism and Hospitality Research, 17(2), 155-167, https://doi.org/10.1080/13032917.2006.9687184

Hall, D. R. (1998). Tourism Development and Sustainability Issues in Central and Southeastern Europe. Tourism Management, 19(5), 423-431, https://doi.org/10.1016/ s0261-5177(98)00039-9

Herzer, D., Nowak-Lehmann, F., Siliverstovs, B. (2006). Export-led Growth in Chile: Assessing the Role of Export Composition in Productivity Growth. The Developing Economies, 44(3), 306-328, https://doi.org/10.1111/j.1746-1049.2006.00019.x

Holtz-Eakin, D., Newey, W., Rosen, H. S. (1988). Estimating Vector Autoregressions with Panel Data. Econometrica, 56(6), 1371-1395, https://doi.org/10.2307/1913103

Hundt, A. (1996). Impact of Tourism Development on the Economy and Health of Third World Nations. Journal of Travel Med, 3(2), 107-112, https://doi.org/10.1111/j.1708-8305.1996. tb00715.x

IMF (2018). Lifting Growth in the Western Balkans - the Role of Global Value Chains and Services Exports. Washington, D.C: International Monetary Fund.

Ivanov, S., Webster, C. (2006). Measuring the Impact of Tourism on Economic Growth. Tourism Economics, 13(3), 379-388, https://doi.org/10.5367/000000007781497773

Kalaitzi, A. S., Cleeve, E. (2018). Export-led Growth in UAE: Multivariate Causality between Primary Exports, Manufactured Exports and Economic Growth. Eurasian Business Review, 8(3), 341-365, https://doi.org/10.1007/s40821-017-0089-1

Kao, C. (1999). Spurious Regression and Residual-Based Tests for Cointegration in Panel Data. Journal of Econometrics, 90(1), 1-44, https://doi.org/10.1016/s0304-4076(98)00023-2

Konan, D. E., Maskus, K. E. (2016). Quantifying the Impact of Services Liberalization in a Developing Country. World Bank Policy. Research Working Paper No. 3193. 
Kordalska, A., Olczyk, M. (2018). CEE Trade in Services: Value Added versus Gross Terms Approaches. Eastern European Economics, 56(4), 269-291, https://doi.org/10.1080/00128 775.2018.1459194

Krenz, A. (2014). Services Sectors Concentration and Countries Specialization Patterns in the European Union: A Comparative Analysis with a Special Focus on France, Germany, Greece and the UK. Regional and Sectoral Economic Studies, 14(1), 23-32.

Kulendran, N., Wilson, K. (2000). Is there a Relationship between International Trade and International Travel? Applied Economics, 32(8), 1001-1009, https://doi.org/10.1080/000368400322057

Lee, C.-C., Chang, C.-P. (2008). Tourism Development and Economic Growth: A Closer Look at Panels. Tourism Management, 29(1), 180-192, https://doi.org/10.1016/j. tourman.2007.02.013

Lorde, T., Lowe, S., Francis, B. (2010). Do Tourism Receipts Contribute to the Sustainability of Current Account Deficits in Barbados? CBB. Working Paper, pp. 1-36.

Loungani, P., Mishra, S., Papageorgiou, C., et al. (2017). World Trade in Services: Evidence from a New Dataset. International Monetary Fund. Washington, D.C Working Paper No. 17/77, https://doi.org/10.5089/9781475589887.001

Mann, C. L. (2004). The US Current Account, New Economy Services, and Implications for Sustainability. Review of International Economics, 12(2), 262-276, https://doi.org/10.1111/j.1467-9396.2004.00448.x

Mishra, S., Lundstrom, S., Rahul, A. (2011). Sophistication in Service Exports and Economic Growth. The World Bank/Economic Premise, No.55.

Moro, A. (2015). Structural Change, Growth and Volatility. American Economic Journal: Macroeconomics, 7(3), 259-294, https://doi.org/10.1257/mac.20130057

Papadopoulos, S. I., Mirza, H. (1985). Foreign Tourism in Greece: An Economic Analysis. Tourism Management, 6(2), 125-137, https://doi.org/10.1016/0261-5177(85)90021-4

Pitre, V., Argade, L. (1988). Measurement of Import Substitution: A sceptical Note. Economic and Political Weekly, 23(5), 215-220.

Priniotaki, I., Kapsisi, S. (2008). Democratization Process And Tourism Industry At The Region Of West Balkans: Tourism as a Socio-political Force. Annals of the University of Oradea, Economic Science Series, 17(1), 450-462.

Proenca, S., Soukiazis, E. (2008). Tourism as an Economic Growth Factor: a Case Study for Southern European Countries. Tourism Economics, 14(4), 791-806, https://doi.org/10.5367/000000008786440175

Samimi, A., Sadeghi, S., Sadeghi, S. (2011). Tourism and Economic Growth in Developing Countries: P-VAR Approach. Middle-East Journal of Scientific Research, 10(1), 28-32.

Santos-Paulino, A. U. (2011). Trade Specialization, Export Productivity and Growth in Brazil, China, India, South Africa, and a Cross Section of Countries. Economic Change and Restructuring, 44(1-2), 75-97, https://doi.org/10.1007/s10644-010-9087-3 
Sequeira, T., Campos, C. (2005). International Tourism and Economic Growth: A Panel Data Approach. FEEM. Working Paper No. 141.05, https://doi.org/10.2139/ssrn.855985

Steingress, W. (2015). Specialization Patterns in International Trade. Banque de France. Working Paper No. 542, https://doi.org/10.2139/ssrn.2579591

Thano, R. (2015). The Impact of Tourism on the Balance of Payments. American Journal of Economics, Finance and Management, 1(5), 529-536.

Timmer, M., Miroudot, S., Gaaitzven, J. (2019). Functional Specialization in Trade. Journal of Economic Geography, 19(1), 1-30, https://doi.org/10.1093/jeg/lby056

Walterskirchen, E. (1998). High Economic Growth in 1998, but Increasing Risks in 1999. Economic Outlook for 1998 and 1999. Austrian Economic Quarterly, 3(4), 167-175.

World Economic Forum (2017). The Travel \& Tourism Competitiveness Report 2017. Geneva: World Economic Forum. 